\title{
Isolation and Characterization of Chinese Hamster Cells Defective in Cell-cell Coupling via Gap Junctions
}

\author{
KLAUS WILLECKE, DAGMAR MÜLLER, PETRA MARIA DRÜGE, \\ UWE FRIXEN, REINHOLD SCHÄFER, \\ ROLF DERMIETZEL' and DIETER HÜLSER ${ }^{2}$ \\ ${ }^{1}$ Institut für Zellbiologie and Institut für Anatomie, Universität Essen, D-4300 Essen I, \\ and ${ }^{2}$ Biologisches Institut, Universität Stuttgart, D-7000 Stuttgart 60, Germany
}

\section{SUMMARY}

Chinese hamster Wg3-h-o cells which were descended from DON cells have been mutagenized and selected for derivatives defective in metabolic cooperation via gap junctions (i.e., $\mathrm{mec}^{-}$). The selection protocol included four consecutive cycles of cocultivating mutagenized cells, deficient in hypoxanthine phosphoribosyltransferase (HPRT) and wild-type cells in the presence of thioguanine (cf Slack, C, Morgan, R H M \& Hooper, M L, Exp cell res 117 (1978) 195-205) [8]. We carried out the last two selection cycles in the presence of 1 mM dibutyryl cyclic adenosine monophosphate (db-cAMP). The isolated Chinese hamster CI-4 cells which expressed the mec ${ }^{-}$phenotype most stringently showed the following characteristics:

1. In standard culture medium no cell-cell coupling was detected among CI-4 cells when assayed by injections of the fluorescent dye Lucifer yellow or by electrical measurements. Between 73 and $100 \%$ of the mec $^{+}$parental cells were coupled under these conditions. Up to $14 \%$ positive contacts were found between CI-4 cells and Chinese hamster Don cells $\left(\mathrm{mec}^{+}\right)$. Confluent CI-4 cells grown in the presence of $1 \mathrm{mM}$ db-cAMP showed $9 \%$ coupled cells.

2. No gap junction plaques were found on electron micrographs of freeze-fractured, confluent CI- 4 cells. The $\mathrm{mec}^{+}$parental cells showed small gap junction plaques $(0.013 \%$ of the total cell surface analyzed).

3. CI-4 cells exhibited $16 \%$ positive contacts and the parental Wg3-h-o cells showed $92 \%$ positive contacts in autoradiographic measurements of metabolic cooperation with DON cells. On an extracellular matrix, prepared from normal embryonic fibroblasts, metabolic cooperation between CI-4 and DON cells was autoradiographically measured to be $68 \%$. Other cells of spontaneous $\mathrm{mec}^{-}$phenotype (for example mouse L cells or human fibrosarcoma HT1080 cells) also appeared to exhibit increased metabolic cooperation when grown on an extracellular matrix and assayed by autoradiographic measurements. When tested by Lucifer yellow injections, however, only very few positive contacts were found for $\mathrm{CI}-4 / \mathrm{DON}$ cell pairs and no positive contacts were found among mouse $\mathrm{L}$ cells grown on an extracellular matrix.

4. The $\mathrm{mec}^{-}$defect in the genome of CI-4 cells was cured in somatic cell hybrids with mouse embryonic fibroblasts or with mouse embryonal carcinoma cells. The results of isozyme and karyotype studies of $\mathrm{mec}^{-}$, as well as mec ${ }^{+}$somatic cell hybrids suggest that mouse chromosome 16 may be involved in complementation of the mec ${ }^{-}$defect.

Most cells in organs and in tissue culture show cell-cell coupling via gap junctions which can be demonstrated by the spreading of electrical signals, injected fluorescent dyes or radioactively labelled metabolites between contiguous cells $[1,2]$. In many cases gap junction plaques, i.e., arrays of particles of polygonal symmetry, have been demonstrated by different techniques of electron microscopy on apposed membranes of contiguous cells. Since the appearance of gap junction plaques and the demonstration of cell-cell coupling (by one or more of 
the methods mentioned above) normally go together, it is generally assumed that gap juction plaques are the morphologically recognizable structures responsible for cell-cell coupling [3]. The final proof for this hypothesis is still lacking, however.

Unfortunately no compound is known which specifically inhibits the function of gap junctions. Spontaneous genetic defects of metabolic cooperation via gap junctions have been described in several tumorigenic cells, particularly in mouse L cells [4]. Recently, it was shown, however, that $L$ cells can form functional gap junctions when cultivated in the presence of cyclic adenosine monophosphate (cAMP) or when induced for increased levels of intracellular cAMP [5]. Wright et al. [6] first described the selection and isolation of variant cells defective in metabolic cooperation $\left(\mathrm{mec}^{-}\right)$from polyoma virus-transformed Syrian hamster cells. These authors selected for cells which survived the conditions of cocultivating thymidine kinase-deficient cells and wild-type cells in the presence of 5bromodeoxyuridine. The $\mathrm{mec}^{-}$deficiency of the isolated variant cells could be reversed by treatment with db-cAMP and theophylline [7]. In the second example of selecting $\mathrm{mec}^{-}$variant cells, Hooper and coworkers isolated and characterized derivatives of embryonal carcinoma cells which were deficient in the enzyme hypoxanthine phosphoribosyltransferase (HPRT, EC 2.4.2.8) [8, 9]. The HPRT ${ }^{-}$ cells were cocultivated with HPRT $^{+}$cells in the presence of thioguanine which killed all HPRT $^{+}$cells and in addition those HPRT $^{-}$cells which had taken up phosphorylated thioguanine from $\mathrm{HPRT}^{+}$cells. Among the surviving cells, one cell line was found which showed a 5-fold reduction in metabolic cooperation (measured autoradiographically by incorporation of $\left[{ }^{3} \mathrm{H}\right]$ hypoxanthine) under conditions of heterotypic cocultivation and a 5-fold reduction in the size or frequency of gap junction plaques detected by electron microscopy of homotypic cultured cells [10]. A revertant of this $\mathrm{mec}^{-}$variant showed restored metabolic cooperation and an increased area of gap junction plaques [11].

All mentioned examples of selected $\mathrm{mec}^{-}$variants showed residual cell-cell coupling or some remaining gap junction plaques or restoration of metabolic cooperation in the presence of cAMP. Apparently cAMP increases-by an unknown mechanism-the capability of $\mathrm{mec}^{-}$cells to form functional cell-cell

Table 1. Survival cloning in consecutive selection cycles during enrichment of Chinese hamster mec $^{-}$cells

\begin{tabular}{lll}
\hline Selection cycle & \% survival cloning & \\
\hline First & CI-1: 0.006 & CII-1:0.006 \\
Second & CI-2:55 & CII-2: 20 \\
Third & CI-3:59 & CII-3:60 \\
Fourth & CI-4:71 & CII-4: 71
\end{tabular}

As outlined under Materials and Methods the Chinese hamster cell lines Wg3-h-o-T (HPRT ${ }^{-}$) and DON (HPRT ${ }^{+}$) were (co)cultured in the presence of thioguanine $(40 \mu \mathrm{g} / \mathrm{ml})$. Percentages of survival cloning were calculated in the following way:

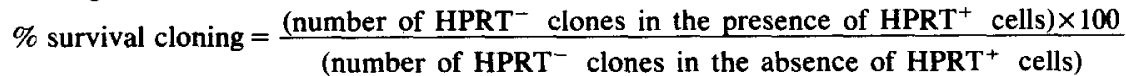


contacts. Therefore we decided to select for $\mathrm{mec}^{-}$cells in the presence of cAMP. Non-leaky mec ${ }^{-}$cells may prove to be very valuable recipient cells for functional integration of isolated gap junction protein, e.g., by fusion with liposomes. As parental cells for the isolation of $\mathrm{mec}^{-}$derivatives we chose established Chinese hamster fibroblasts. We wanted to study complementation of the $\mathrm{mec}^{-}$defect by one or more mouse chromosomes in somatic cell hybrids of $\mathrm{mec}^{-}$Chinese hamster cells and $\mathrm{mec}^{+}$mouse cells.

\section{MATERIALS AND METHODS}

\section{Cells and cell culture}

Chinese hamster DON cells were purchased from the American Type Culture Collection. The DON derived Wg3-h-o cells, defective in HPRT and resistant towards $3 \mathrm{mM}$ ouabain, have been described in a previous paper from this laboratory [12]. Wg3-h-o-T cells were derived from a tumor growing subcutaneously in a nude mouse 3 weeks after injection of $5 \times 10^{6} \mathrm{Wg} 3-\mathrm{h}-\mathrm{o}$ cells. The isolation of mec $^{-}$CI-4 cells is described below. The mouse embryonal carcinoma cell line OC15S1 was obtained from Dr McBurney [13]. Embryonic mouse or Chinese hamster fibroblasts were isolated as previously described [12]. The L cell derivatives A9 and LMTK $^{-}$have been used in several studies of somatic cell genetics from this laboratory [cf 14]. HT1080-T4 cells are an HPRT ${ }^{-}$derivative of the human fibrosarcoma cell line HT1080 which had been obtained from the American Type Culture Collection (CCL 121). The parental cells had been mutagenized with $N$-methyl- $N^{\prime}$-nitro- $N$-nitrosoguanidine (1 $\mu \mathrm{g} / \mathrm{ml}$ PBS for $2 \mathrm{~h}$ at $\left.37^{\circ} \mathrm{C}\right)$ and cloned in the presence of thioguanine $(10 \mu \mathrm{g} / \mathrm{ml})$. HT1080-T4 cells do not grow in HAT-selective medium (see below). Human GM38 fibroblasts were purchased from the Human Gene Mutant Repository, Cambden, NJ.

All cells were grown in the low glucose modification of Dulbecco's modified Eagle's medium in the presence of $10 \%$ fetal bovine serum, penicillin and streptomycin (each $50 \mu \mathrm{g} / \mathrm{ml}$ ) (standard medium). HAT-selective medium [15] contained in addition hypoxanthine $(13.6 \mu \mathrm{g} / \mathrm{ml})$, aminopterin $(0.19 \mu \mathrm{g} / \mathrm{ml})$ and thymidine $(3.9 \mu \mathrm{g} / \mathrm{ml})$ [16]. Cell lines and somatic cell hybrids used in this study were free of mycoplasma when assayed in the fluorescence assay using the benzimidazol dye Hoechst 33258 [17].

\section{Mutagenesis and selection of cells defective in metabolic cooperation}

$\mathrm{Wg} 3$-h-o-T cells growing logarithmically in standard medium were washed twice in phosphatebuffered saline (PBS) and incubated with $N$-methyl- $N^{\prime}$-nitro- $N$-nitrosoguanidine ( $1 \mu \mathrm{g} / \mathrm{ml}$ PBS) for $1.5 \mathrm{~h}$ at $37^{\circ} \mathrm{C}$. Then the cells were washed again 3 times in PBS, trypsinized, and diluted $1: 5$ before being replated.

The following conditions of cocultivation and selection are a modified protocol of the procedure originally described by Slack et al. [8]. Four days after mutagenesis $1 \times 10^{5} \mathrm{Wg} 3$-h-o-T cells mixed with $3.5 \times 10^{6}$ DON cells were seeded per $75 \mathrm{~cm}^{2}$ tissue culture flask (Falcon). Twenty-four hours later 6-thioguanine $(40 \mu \mathrm{g} / \mathrm{ml})$ was added to the standard culture medium. After 2 further days many DON cells were detached due to action of the drug. At days 3, 5 and 6 the cultures were washed with standard medium and $4 \times 10^{6} \mathrm{DON}$ cells were added per $75 \mathrm{~cm}^{2}$ tissue culture flask. The thioguanine concentration was restored to $40 \mu \mathrm{g} / \mathrm{ml}$ about $10 \mathrm{~h}$ after adding the fresh DON cells. Clones were isolated with stainless steel cylinders 9-12 days after start of the cocultivation. On the average one clone in $2.5 \times 10^{4} \mathrm{Wg} 3-\mathrm{h}-\mathrm{o}-\mathrm{T}$ cells was detected.

Table 1 summarizes the percentages of survival cloning obtained with derivatives of the mutagenized Wg3-h-o-T cells at different steps of the selection. Survival cloning efficiency is defined as the ratio of the cloning efficiency, found in the presence of a 12- to 50-fold excess of donor DON cells, over the cloning efficiency found in its absence [cf 8]. Out of twelve clones picked after the first selection cycle four clones were discarded due to slow growth and the remaining ones were tested in the second selection cycle. The clones CI-1 and CII-1 showed the highest percentages of survival and the highest relative cloning efficiencies.

Two hundred Cl-1 or CII-1 cells were mixed in duplicate with $1.5 \times 10^{6}$ logarithmically growing DON cells per $25 \mathrm{~cm}^{2}$ tissue culture flasks. $24 \mathrm{~h}$ later thioguanine $(40 \mu \mathrm{g} / \mathrm{ml})$ was added. At days 5 and 7 , each time $1.5 \times 10^{6}$ DON cells were added in the same way as outlined above. Six derivatives of two clones (CI-2 and CII-2) showing the highest cloning efficiencies were picked and subjected to the third selection cycle.

The third selection cycle was carried out with the same cell numbers as used in the second selection 
cycle except that $1 \mathrm{mM}$ db-cAMP was added at the time of cocultivation, followed by thioguanine (40 $\mu \mathrm{g} / \mathrm{ml}) 24 \mathrm{~h}$ later. No additional DON cells were added after start of the cocultivation experiment, since in the presence of cAMP the DON cells detached only very slowly from the plastic surface. The cloning efficiencies of CI-3 and CII-3 cells in the presence of $1 \mathrm{mM} \mathrm{db}-\mathrm{cAMP}$ were only $50-60 \%$ of those found in the absence of cAMP.

The conditions of the fourth selection cycle were identical to the ones described for the third cycle. In the presence of $1 \mathrm{mM} \mathrm{db}$-cAMP three derivatives each of the $\mathrm{Cl}-3$ and $\mathrm{CII}-3$ cells were tested. The cloning efficiencies in the cocultivation assays were found to be the same in the presence and absence of db-cAMP. The derived clones CI-4 and CII-4 showed the highest percentages of survival cloning (table 1 and were analyzed for cell-cell coupling by other methods (see below).

\section{Microinjection of the fluorescent dye Lucifer yellow into cultured cells}

Capillaries were drawn from AR glass (outer diameter, $1.0 \mathrm{~mm}$; inner diameter, $0.76 \mathrm{~mm}$, Hilgenberg, Germany) which had been siliconized (1\% aqueous solution of Siliclad, Becton-Dickinson) at room temperature, followed by extensive washings. In our experience siliconized capillaries allowed more reproducible injection. A dual step capillary puller (Narishige, Japan) was used with empirical settings of the magnetic drawing forces. The capillaries were fixed in a microcapillary holder of a micromanipulator connected via appropriate tubing to a $50 \mathrm{ml}$ syringe and filled by aspirating a solution of Lucifer yellow (CH) (gift of Dr W. Stewart, NIH, Bethesda) [18] (457 D; $10 \%$ in 0.33 M lithium chloride solution) through the tip. The cells were grown for $24-48 \mathrm{~h}$ on round glass coverslips (diameter, $13 \mathrm{~mm}$ ) usually up to about $70 \%$ confluency, if not indicated otherwise, in standard medium. The coverslips were placed in Petri dishes $(35 \mathrm{~mm})$ fitting into an appropriate holder under an inverted microscope (Diavert, Leitz) equipped with fluorescence epi-illumination and a filter combination (E2) which allowed optimal analysis of injected Lucifer yellow. The cells were impaled at $23^{\circ} \mathrm{C}$ with capillaries, usually close to the nucleus, and dye was injected by hand pressure on the $50 \mathrm{ml}$ syringe. This technique is similar to the one used by Grässmann et al. [19]. During injections the culture medium in the Petri dish was continuously gassed with $\mathrm{CO}_{2}$ through a sterile filter placed in an appropriate position in order to maintain a $\mathrm{pH}$ of about 7.5 . Ten to $30 \mathrm{~min}$ after each injection the spreading of Lucifer yellow into neighbouring cells was analyzed in fluorescence light. Injection and analysis of cells in 10-20 overlapping view fields of the microscope usually took $1-2 \mathrm{~h}$. The fluorescence of the dye spread into neighbouring cells could be seen up to $5 \mathrm{~h}$ after injection. When it was difficult to decide whether thin plasma bridges existed between cells in close contact, a solution of human serum albumin ( $7 \mathrm{mg} / \mathrm{ml}$ PBS), labelled with rhodamine isothiocyanate, was coinjected with Lucifer yellow into the cells. When plasma bridges existed between cells the rhodamine-derived fluorescence spread into contiguous cells. In the absence of plasma bridges, Lucifer yellow fluoresence spread into contiguous cells, whereas the rhodamine-derived fluorescence remained in the injected cell.

\section{Electrical coupling}

About $4 \times 10^{6}$ freshly trypsinized cells (or $2 \times 10^{6}$ cells of each type) were plated in Petri dishes $(60 \mathrm{~mm}$ diameter) and grown for at least $24 \mathrm{~h}$ in standard medium. Pairs of contiguous cells were impaled at $20^{\circ} \mathrm{C}$ with microelectrodes filled with $3 \mathrm{M} \mathrm{KCl}$, tip potentials $<5 \mathrm{mV}$. Rectangular pulses of current (about $2 \times 10^{-8} \mathrm{~A}$, inwards) were used to trace the existence of low resistance junctions between the impaled cell pairs [20]. The electrode resistances were $20 \mathrm{M} \Omega$.

In order to distinguish DON cells from CI-4 or Cll-4, the latter cells were grown in the presence of sterile latex beads ( $1.04 \mu \mathrm{m}$ diameter, about $2 \times 10^{7}$ beads per $\mathrm{ml}$ standard medium) for 2 days. Then the cells were trypsinized and washed four times in PBS before being plated for the cocultivation experiment. Under these conditions more than $99 \%$ of the CI-4 or CII-4 cells contained at least five beads per cell.

\section{Electron microscopy}

Cultures of Wg3-h-o-T and Cl-4 cells were washed with PBS, fixed in situ with $2.5 \%$ glutaraldehyde for $1 \mathrm{~h}$ and washed again three times with PBS. Then the cells were scraped off the dish with a razor blade wrapped with Teflon tape. After centrifugation (10 min, $1000 \mathrm{~g}$ ) the pellet was glycerinated by a graded series of glycerol in Ringer solution. The final glycerol concentration was $30 \%$. The samples were placed on commercial specimen discs and frozen in Freon 22, cooled by liquid nitrogen. Fracturing of the samples was done in a Balzers high vaccum unit (BAF $400 \mathrm{D}$ ). The fractured cells were shadowed with $2 \mathrm{~nm}$ of platinum/carbon, evaporated by an electron gun, and the replicas 
reinforced with carbon. The cells were digested in chlorax and the replicas mounted on two hundred mesh copper grids.

Morphometry. Selected areas of $4.6 \mu \mathrm{m}^{2}$ of the replicas as bounded by mark on the electron microscope screen, were scanned at $\mathbf{4 6 0 0 0}$ magnification. In order to minimize the amount of uncontacted area only those membranes were scanned which were in close apposition to neighbouring cells. The acceptance criterion for close apposition was the presence of a P-E transition on fracture faces in the scanned areas. Areas of gap junctions were integrated with the aid of a Leitz ASM curve digitizer, on electron micrographs at a magnification of 80000 .

\section{Assay of metabolic cooperation}

The conditions were similar as described in the literature [21]. $1 \times 10^{4} \mathrm{HPRT}^{-}$.cells were mixed with $1 \times 10^{3} \mathrm{HPRT}^{+}$cells and seeded per $\mathrm{cm}^{2}$ surface onto round glass coverslips (13 mm diameter) which were placed in Petri dishes $(60 \mathrm{~mm})$ or in the wells of Costar plates. After $24 \mathrm{~h}$ the standard medium was replaced for $5 \mathrm{~h}$ by fresh medium containing $5 \mu \mathrm{Ci} / \mathrm{ml}\left[{ }^{3} \mathrm{H}\right]$ hypoxanthine (sp. act. $4.3 \mathrm{Ci}$ per mmole). Afterwards the cultures were washed three times with PBS, once with isopropanol (95\%, 10 $\mathrm{min}$ ) at room temperature, twice at $4^{\circ} \mathrm{C}$ with trichloroacetic acid (TCA) (10\%) for $10 \mathrm{~min}$, three times at room temperature with bidestilled $\mathrm{H}_{2} \mathrm{O}$ and three times with methanol. The moist coverslips were glued with DePeX (Gurr), cell side up, onto object slides and dried for $24 \mathrm{~h}$ at room temperature. Then the coverslips were bathed in $0.5 \%$ gelatine at $37^{\circ} \mathrm{C}$ and dried while standing in an upright position for 12-20 $\mathrm{h}$ at room temperature. Autoradiography was carried out with Kodak AR10 stripping film for about $100 \mathrm{~h}$. After development of the film, the cells on the slides were stained with toluidine blue $(0.06 \%$ in $16 \%$ methanol and $17 \%$ PBS). Under these conditions the nuclei and the cytoplasm of the donor cells were densely labelled with silver grains on the film, whereas recipient cells located more than four cell diameters away from donor cells showed very low labelling of the nuclei similar to the background. The nuclei of Wg3-h-o recipient cells contiguous to DON cells showed excessive labelling. In order to estimate the extent of metabolic cooperation, the silver grains over fifty recipient cells in contact to donor cells and grains over fifty recipient cells without this contact were counted and the results were plotted. The percentage of cells exhibiting metabolic cooperation was calculated by using the 90th percentile method as suggested by Gaunt \& Subak-Sharpe [21]. Briefly, the numbers of grains over recipient cells without contact to donor cells were counted and used to determine the value below which $90 \%$ of these numbers could be grouped. This value was multiplied by a factor of 2 and then used as threshold value. All recipient cells in contact with donor cells showing numbers of grains above this threshold were assumed to be metabolically coupled. The data from different experiments involving the same cell pairs were checked for homogeneity using the F-test (5\% confidence interval).

\section{Preparation of the extracellular matrix}

The cell-free, extracellular matrix was prepared from nearly confluent cultures of embryonic fibroblasts (BALB/c mouse, Chinese hamster or human (GM38)), using the detergent NP40, according to Chen [22].

\section{Isolation of somatic cell hybrids}

Cl-4 cells $\left(0.8 \times 10^{6}\right)$ and embryonal carcinoma OC15S1 cells $\left(4 \times 10^{6}\right)$ were mixed and seeded per tissue culture flask ( $75 \mathrm{~cm}^{2}$, Lux). Twenty-four hours later fusions were carried out with polyethylene glycol (MW 1540, Roth, Karlsruhe) exactly as described previously [12]. Selection medium (HAT plus $3 \mathrm{mM}$ ouabain) was added one day after the fused cells had been $1: 10$ diluted. Two weeks later on the average 3-4 clones were detected per flask of the fused, diluted cells. No clone was seen when $4 \times 10^{6}$ OC15S1 cells were maintained in selection medium. Thus it was unlikely that the surviving clones were due to spontaneous occurrence of ouabain resistance in this cell line. Ten clones (designated OW hybrids) from different flasks were picked with stainless steel cylinders and grown up in standard medium containing: hypoxanthine $(13.6 \mu \mathrm{g} / \mathrm{ml})$ and thymidine $(3.9 \mu \mathrm{g} / \mathrm{ml})$ [23] for 5 days, no additions for 3 days, thioguanine $(40 \mu \mathrm{g} / \mathrm{ml})$ for 3 days, thioguanine $(10 \mu \mathrm{g} / \mathrm{ml})$ for 3 weeks, and no additions thereafter. BW somatic cell hybrids were derived from fusions of CI-4 cells with embryonic BALB/c mouse fibroblasts. A 10-50 excess of the latter cells was used in order to avoid fusions of two Cl-4 cells with each other [24]. For BW hybrids the fusion protocol, the selection system in standard medium containing HAT and $1 \mathrm{mM}$ ouabain, the isolation of the clones and the counter selection protocol with thioguanine were identical as detailed above for OW hybrids. 

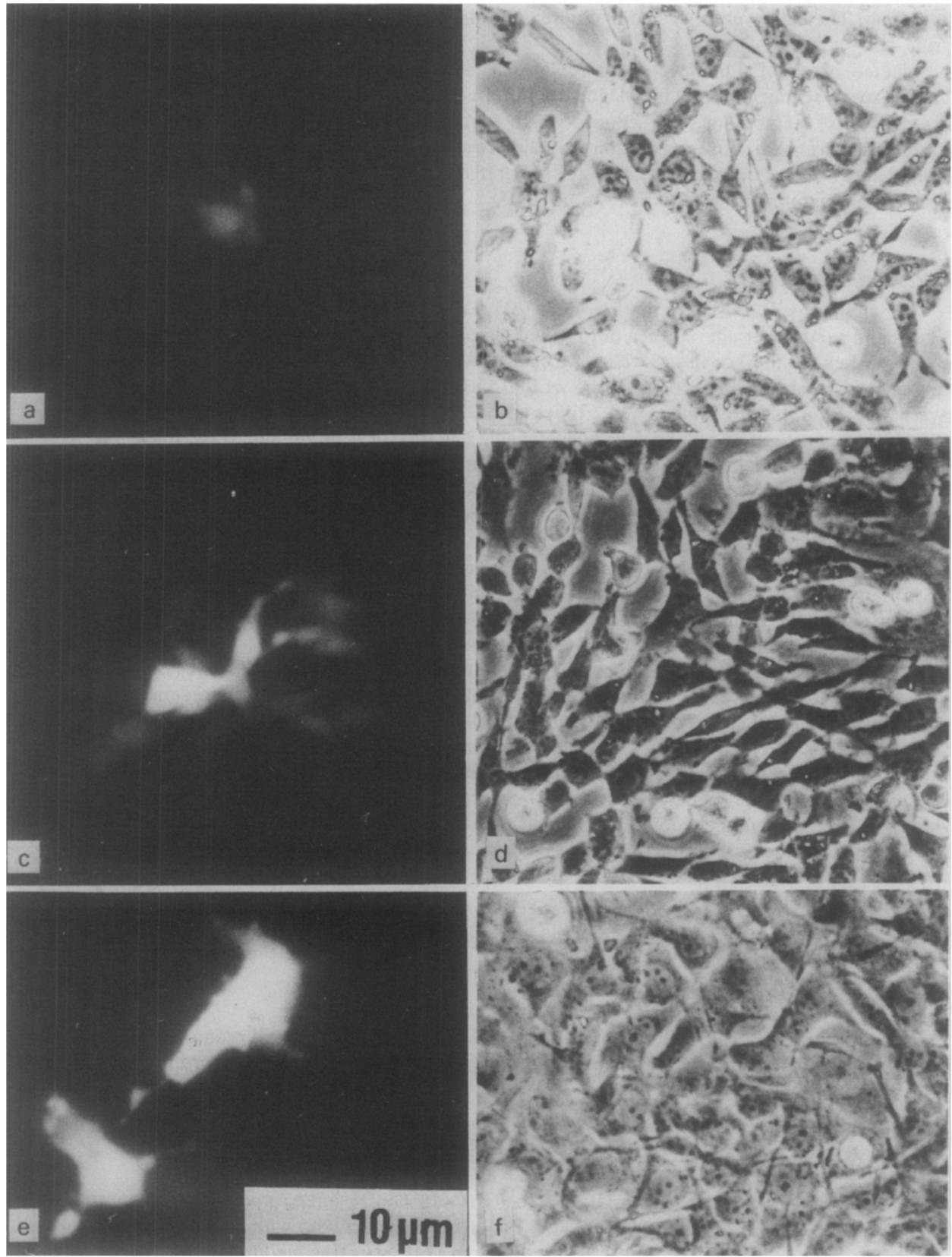

Fig. 1. Cell-cell coupling analyzed after microinjection of Lucifer yellow. Lucifer yellow was injected into the following cell lines $(a, b) \mathrm{CI}-4 ;(c, d) \mathrm{Wg} 3-\mathrm{h}-\mathrm{o}-\mathrm{T}$, and $(e, f) \mathrm{CI}-4(100 \%$ confluent, growing in the presence of $1 \mathrm{mM} \mathrm{db}$-cAMP). The same areas were photographed on Ilford HP5 film in $(a, c, e)$ fluorescence light; $(b, d, f)$ under phase contrast conditions, in order to show the morphology of the cultured cells. Exposure times: $15 \mathrm{sec}$ to 2 min, depending on the brightness of the microscopic image.

\section{Isozyme analyses of cell hybrids}

The preparation of cell extracts and the isozyme electrophoresis were carried out as previously described [25]. We assayed the expression of seventeen mouse isozyme genes, all of which had been assigned to different mouse chromosomes: 
Acid phosphatase (ACP-1, EC 3.1.3.2), adenylate kinase (AK-1, EC 2.7.4.3.), adenine phosphoribosyltransferase (APRT, EC 2.4.2.7.), esterase (ES-10, EC 3.1.1.1), mannose phosphate isomerase (MPI, EC 5.3.1.8), phosphoglucomutase (PGM-1 and PGM-2, EC 2.7.5.1), glucose phosphate isomerase (GPI, EC 5.3.1.9), peptidase (PEP-1, PEP-2, PEP-3, EC 3.4.1.1), glyoxydase (GLO-1, EC 4.4.1.5), galactokinase (GALK, EC 2.7.1.6), glutamateoxaloacetate transaminase (GOT-1, EC 2.6.1.1), hypoxanthine phosphoribosyltransferase (HPRT, EC 2.4.2.8), superoxide dismutase (SOD1, EC 1.15.1.1), and triose phosphate isomerase (TPI, EC 5.3.1.1).

\section{Chromosome analyses}

Karyotype analyses were carried out as previously reported [25].

\section{RESULTS}

\section{Selection of Chinese hamster cells defective in metabolic cooperation}

HPRT $^{-}$cells are resistant against addition of thioguanine in the culture medium, since they lack the enzyme for phosphorylation of this purine analog. During cocultivation of HPRT $^{-}$and $\mathrm{HPRT}^{+}$cells, however, the lethal, phosphorylated products of thioguanine are synthesized in $\mathrm{HPRT}^{+}$cells and can be transferred via gap junctions into HPRT ${ }^{-}$cells, thereby killing these recipient cells. Defects in the function of gap junctions and probably other defects as well can prevent this "kiss of death" phenomenon [2, 9]. Thus the progress in the selection procedure for $\mathrm{mec}^{-}$cells can be monitored by the extent of survival of HPRT cells in the presence of thioguanine and an excess of HPRT ${ }^{+}$cells. For better comparison we expressed the results of the different selection cycles for isolation of mec $^{-}$mutants as percentages of relative cloning efficiencies of HPRT ${ }^{-}$cells in the presence and absence of $\mathrm{HPRT}^{+}$cells in thioguanine containing standard medium (table 1).

HPRT $^{-}$cells defective in metabolic cooperation with HPRT $^{+}$cells should show a relative survival cloning of $100 \%$. However, this expectation was never completely fulfilled. The highest increase in survival cloning was obtained after the first selection cycle (see table 1). A similar result has been observed by Slack et al. [8] during isolation of $\mathrm{mec}^{-}$derivatives of mouse embryonal carcinoma cells. In our experience the repeated feeding of the selection flasks with HPRT $^{+}$ cells (see Materials and Methods) decreased the number of clones derived from HPRT $^{-}$cells by at least a factor of five. Apparently under our conditions of cocultivation many of the HPRT ${ }^{-}$cells did not have enough cell-cell contacts with $\mathrm{HPRT}^{+}$cells to be efficiently killed without repeated feedings.

There are reports from two laboratories $[5,7]$ that addition of cAMP to the culture medium or an increase of intracellular cAMP led to an increase in junctional permeability between cultured $\mathrm{mec}^{-}$cells. Therefore we decided to select cells exhibiting the $\mathrm{mec}^{-}$phenotype in the presence of $1 \mathrm{mM} \mathrm{db}-\mathrm{cAMP}$ during the third and fourth selection cycle. Although in the third selection cycle all cells yielded only about half the number of clones when db-cAMP had been added to the culture medium, the percentage of survival cloning increased only marginally (table 1). In the fourth selection cycle the number of clones obtained in the presence of db-cAMP was about the same as in its absence. The clones CI4 and CII- 4 were isolated and subjected to further analysis. 
Table 2. Cell-cell coupling detected after microinjection of Lucifer yellow

\begin{tabular}{|c|c|c|c|}
\hline $\begin{array}{l}\text { Name of cells } \\
\text { in contact }\end{array}$ & $\begin{array}{l}\text { Total no. of } \\
\text { injected cells }\end{array}$ & $\begin{array}{l}\text { No, of positive } \\
\text { contacts }\end{array}$ & $\begin{array}{l}\% \text { of positive } \\
\text { contacts }^{b}\end{array}$ \\
\hline Wg3-h-o/Wg3-h-o & 58 & 50 & 86 \\
\hline Wg3-h-o-T/Wg3-h-o-T & 40 & 29 & 73 \\
\hline $\mathrm{CI}-4 / \mathrm{CI}-4$ & 38 & 0 & 0 \\
\hline $\mathrm{CI}-4 / \mathrm{CI}-4$ & $32^{c}$ & 0 & 0 \\
\hline $\mathrm{CI}-4 / \mathrm{CI}-4$ & $94^{d}$ & 0 & 0 \\
\hline $\mathrm{CI}-4 / \mathrm{CI}-4$ & $96^{\mathrm{e}}$ & 9 & 9 \\
\hline $\mathrm{CI}-4 / \mathrm{CI}-4$ & $39^{f}$ & 0 & 0 \\
\hline $\mathrm{CI}-4 / \mathrm{DON}^{\mathrm{g}}$ & 46 & 0 & 0 \\
\hline $\mathrm{CI}-4 / \mathrm{DON}^{\mathrm{g}}$ & $27^{r}$ & 2 & 7 \\
\hline CII-4/CII-4 & 25 & 4 & 16 \\
\hline A98/LMTK ${ }^{-}$ & $56^{f}$ & 0 & 0 \\
\hline
\end{tabular}

For details of culture conditions, microinjections and fluorescence microscopy, see Materials and Methods. a No. of cases where spreading of Lucifer yellow to at least one contiguous cell has been observed. $\quad{ }^{b}$ For comparison we expressed the number of positive contacts in this table (as well as in tables 3 and 7) as percentages of the total number of injected cells, although the number of measurements was often far below $100 . \quad{ }^{c} 10-20 \%$ confluency. ${ }^{d} 10-20 \%$ confluency, grown for $24 \mathrm{~h}$ in the presence of db-cAMP $(1 \mathrm{mM})$. $\quad 100 \%$ confluency, grown for $24 \mathrm{~h}$ in the presence of $\mathrm{db}$ CAMP (1 mM). ' Grown for $24 \mathrm{~h}$ on an extracellular matrix (for preparation see Materials and Methods). $\quad{ }^{g}$ Before coculturing this cell line had been grown for $48 \mathrm{~h}$ in the presence of latex beads in order to distinguish if from the partner cell line. Beads-labelled as well as non-labelled cells in contact were microinjected with Lucifer yellow.

\section{Cell-cell coupling measured after microinjection of Lucifer yellow}

We followed the spreading of the microinjected fluorescent Lucifer yellow between contiguous cells in order to compare the junctional permeability in $\mathrm{mec}^{-}$ and parental cells (dye transfer). The results are summarized in table 2 . Whereas we found for cultures of the Wg3-h-o and Wg3-h-o-T cells $86 \%$ and $73 \%$ positive contacts, respectively, frequently for groups of cells, no "dye transfer" was observed under the same assay conditions between the mec ${ }^{-} \mathrm{CI}-4$ cells. Only when confluent cultures of CI-4 cells, grown for $24 \mathrm{~h}$ in the presence of $1 \mathrm{mM} \mathrm{db}$ sAMP were assayed, $9 \%$ of the injected cells appeared to be coupled as well

Table 3. Measurements of low resistance junctions

\begin{tabular}{|c|c|c|c|c|}
\hline $\begin{array}{l}\text { Names of cells } \\
\text { in contact }\end{array}$ & $\begin{array}{l}\text { Total no. } \\
\text { of meas- } \\
\text { urements }\end{array}$ & $\begin{array}{l}\text { No. of } \\
\text { dishes } \\
\text { used }^{a}\end{array}$ & $\begin{array}{l}\text { No. of measurements } \\
\text { showing electrically } \\
\text { coupled cells }\end{array}$ & $\begin{array}{l}\% \text { of positive } \\
\text { contacts }\end{array}$ \\
\hline DON/DON & 10 & 2 & 10 & 100 \\
\hline Wg3-h-o-T/Wg3-h-o-T & 7 & 2 & 7 & 100 \\
\hline $\mathrm{CI}-4 / \mathrm{CI}-4$ & 56 & 10 & 0 & 0 \\
\hline $\mathrm{CI}-4^{b} / \mathrm{DON}$ & 42 & 8 & 6 & 14 \\
\hline CII-4 $/ \mathrm{Wg} 3-\mathrm{h}-0-\mathrm{T}$ & 32 & 6 & 13 & 41 \\
\hline
\end{tabular}

\footnotetext{
a Five measurements were performed on each dish.

$b$ These cells had been prelabelled with latex beads before being cocultivated with DON or Wg3-h-o$\mathrm{T}$ cells (for details see Materials and Methods).
} 
pairs (fig. 1). The second $\mathrm{mec}^{-}$isolate (CII-4) showed $16 \%$ dye-coupled cells under conditions when no coupling was detected between $\mathrm{CI}-4$ cells. Thus the $\mathrm{CI}$ 4 cells expressed the mec ${ }^{-}$phenotype more stringently than the CII- 4 cells. We also investigated whether $\mathrm{CI}-4$ cells exhibited dye-coupling when cocultured with DON cells. In order to distinguish both cells under these conditions one cell partner had been prelabelled with latex beads $(1.04 \mu \mathrm{m}$ diameter $)$. We found no coupled cell pairs of CI-4/DON cells among forty-six trials. However, when the CI-4/DON cells were cocultured on an extracellular matrix prepared from embryonic Chinese hamster fibroblasts, we noticed about $7 \%$ positive contacts.

\section{Measurements of low resistance junction}

We wished to confirm the conclusions drawn from the dye injection assays by an independent method of measuring cell-cell coupling. Thus we tried to trace low resistance junctions by electrical measurements details of which are described under Materials and Methods. Again no contacts were detected among CI-4 cells, whereas all contiguous parental cells (Wg3-h-o-T) were eleccrically coupled. When we investigated low resistance junctions in cocultures of CI-4 cells with DON cells we found six out of forty-two measurements (14\%) to be positive (table 3). Apparently the CI-4 cells are able to exhibit a low level of cell-cell coupling, but only when cocultured with the well-coupling parental cell line. Since the dye injection assays are less sensitive than electrical measurements [1], it is not surprising that we did not detect this low level of cell-cell coupling by the first method (cf table 2). The second isolate (CII-4) of the repeated selection cycles for $\mathrm{mec}^{-}$cells showed in comparison with CI-4 cells 3fold more electrically coupled cell pairs when cocultured with the Wg3-h-o-T

Table 4. Autoradiographic measurements of contacts positive for metabolic cooperation

\begin{tabular}{|c|c|c|c|c|c|}
\hline HPRT $^{-}$cells & HPRT $^{+}$cells & $\begin{array}{l}\text { No. of } \\
\text { experiments }\end{array}$ & $\begin{array}{l}\text { Extracellular } \\
\text { matrix }\end{array}$ & $\begin{array}{l}\text { Threshold } \\
\text { value }^{b}\end{array}$ & $\begin{array}{l}\% \text { positive. } \\
\text { contacts }\end{array}$ \\
\hline Wg3-h-o & DON & 1 & No & 20 & 92 \\
\hline Cl-4 & $\mathrm{DON}^{c}$ & 2 & No & 18 & 16 \\
\hline $\mathrm{Cl}-4$ & DON & 2 & Yes & 12 & 68 \\
\hline A9 & LMTK $^{-}$ & 2 & No & 22 & 40 \\
\hline $\mathrm{A} 9^{\mathrm{C}}$ & LMTK $^{-}$ & 2 & Yes & 16 & 61 \\
\hline HT1080-T4 & HT1080 & 2 & No & 26 & 32 \\
\hline HT1080-T4 & HT1080 & 3 & Yes & 26 & 75 \\
\hline
\end{tabular}

${ }^{a}$ For Chinese hamster cells and mouse A9/LMTK- cells an extracellular matrix prepared from embryonic Chinese hamster fibroblasts and from embryonic mouse fibroblasts (BALB/c) was used, respectively. For HT1080 cells the extracellular matrix was prepared from human GM38 fibroblasts.

${ }^{b}$ The threshold value indicates the minimal number of grains per cell taken as evidence of metabolic cooperation (for details of Gaunt \& Subak-Sharpe [21] and Materials and Methods).

$c$ These cells had been prelabelled with latex beads before cocultivation in order to better distinghuish them from their partner cells. Under these conditions the quantitation of metabolic cooperation between cells was very similar to those experiments in which none of the cells had been prelabelled with latex beads. 


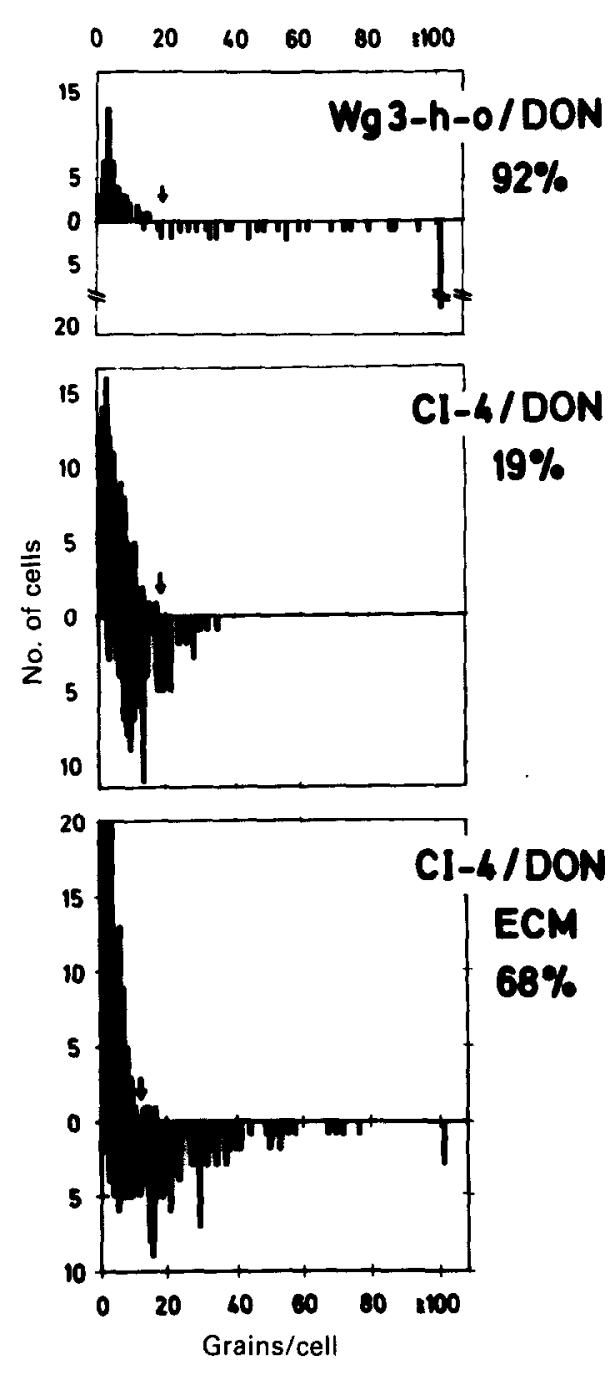

Fig. 2. Autoradiographic analysis of metabolic cooperation. Data were obtained after coculturing the indicated cell lines in the presence of $\left[{ }^{3} \mathrm{H}\right]$ hypoxanthine. In each panel upright histograms show distribution of grain numbers over those HPRT ${ }^{-}$ cells which had no visible contacts to the HPRT $^{+}$ cells on the same coverslips: The inverted histograms show distributions over HPRT $^{-}$cells in close contact with HPRT $^{+}$cells. Arrows, minimum grain numbers (threshold values) taken as evidence of metabolic cooperation (calculated as described in [21]). Percentage values are the proportions of the corresponding contacts positive for metabolic cooperation (cf table 4). ECM means that the cells were cocultured on an extracellular matrix prepared as described under Materials and Methods.

parental cells. Therefore the electrical measurements confirm that the Cl-4 cells exhibit the mec ${ }^{-}$phenotype more stringently than the CII-4 cells.

\section{Autoradiographic measurements of metabolic cooperation}

Subak-Sharpe and coworkers [2] have detected and characterized metabolic cooperation by autoradiographic analysis of the transfer of radioactively labelled nucleotides between contiguous cells in culture. In addition to survival cloning, fluorescent dye injection, and electrical measurement, this was the fourth method which we used to study cell-cell coupling via gap junctions in CI-4 and their parental cells. We found $16 \%$ positive contacts for CI-4/DON cell pairs and $92 \%$ positive contacts for Wg3-h-o/DON cell pairs (table 4, fig. 2). All autoradiographic measurements of Wg3-h-o-T/DON contacts were discarded due to the relatively high autoradiographic background of the recipient cells not in contact with donor cells under these conditions. The autoradiographic analysis of meta- 

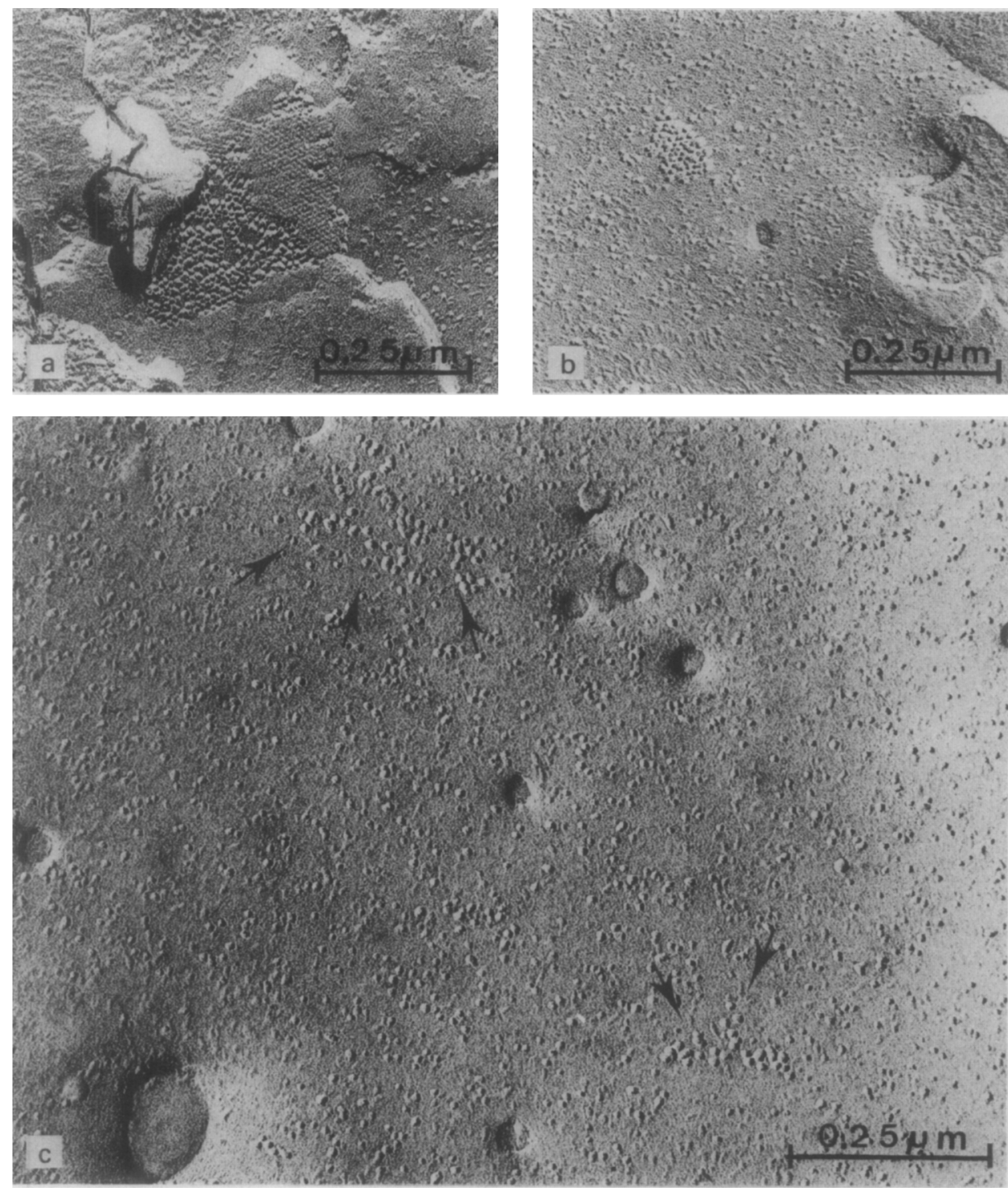

Fig. 3. Freeze-fracture electron micrographs of $\mathrm{Wg} 3-\mathrm{h}-\mathrm{o}$ cells $\left(\mathrm{mec}^{+}\right)$and $\mathrm{CI}-4$ cells $\left(\mathrm{mec}^{-}\right)$. (a) P-E face transition of a gap junction on a Wg3-h-o cell; (b) small-sized gap junction on the P-face of a Wg3h-o cell; (c) particle clusters (arrows) on the P-face of a CI-4 cell.

bolic cooperation according to Gaunt \& Subak-Sharpe [21] is only suitable for situations where the background is low [2].

We wanted to know whether proteins of an extracellular matrix had any effect on cell-cell coupling of cells showing the $\mathrm{mec}^{-}$phenotype. Thus we cocultured these cells on an extracellular matrix prepared on glass coverslips by lysis of nearly confluent embryonic fibroblasts with NP40. Under these conditions we found about $68 \%$ positive contacts between CI-4 and DON cells (table 4). Thus it appears as if an extracellular matrix can restore metabolic cooperation between CI-4/DON cells by a factor of 4 . We noticed that the extracellular matrix also 


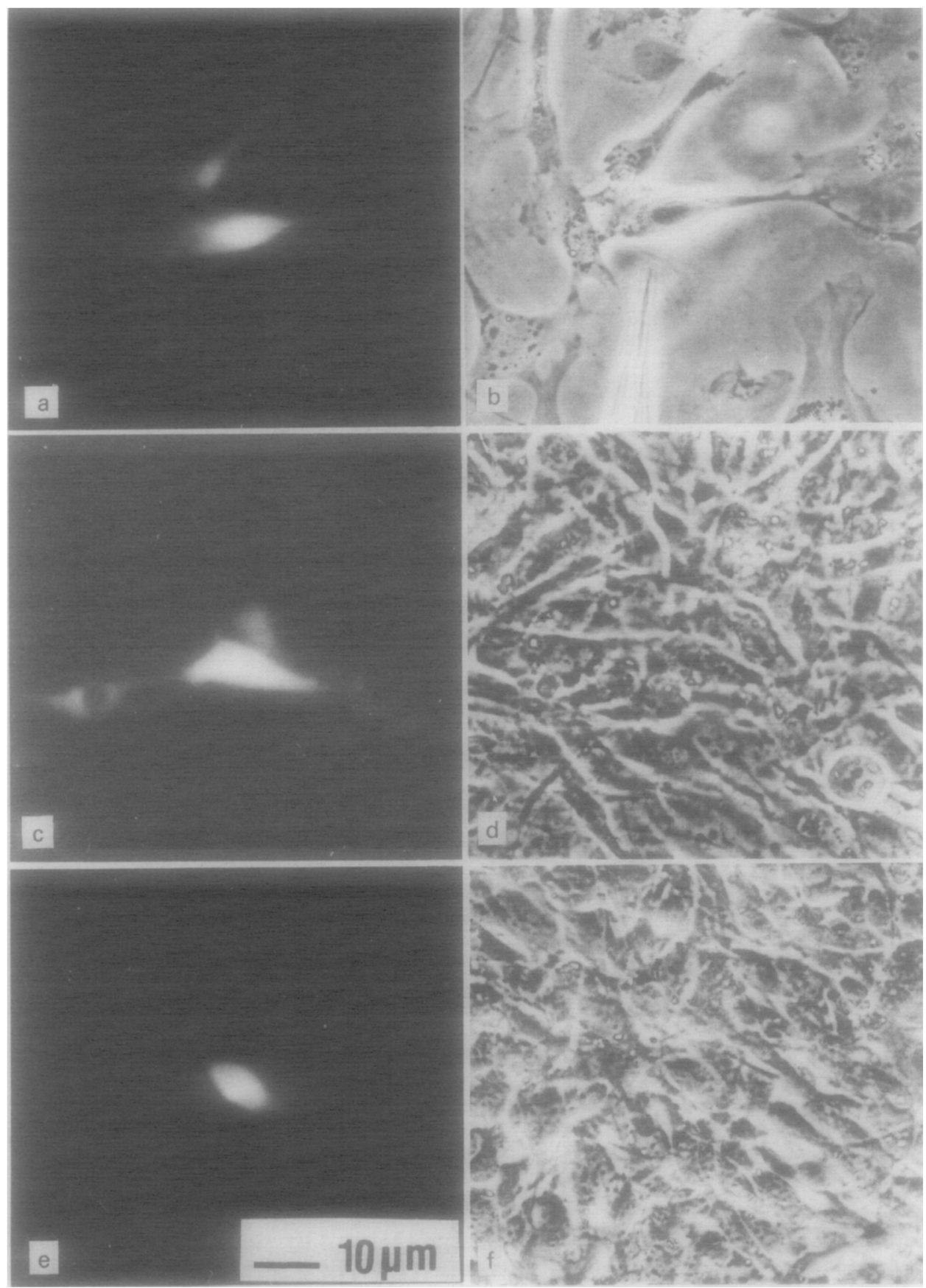

Fig. 4. Cell-cell coupling in somatic cell hybrids analyzed after microinjection of Lucifer yellow. I ucifer yellow was injected into the following hybrid cells. $(a, b) 20 \mathrm{BW} 4 ;(c, d)$ OW6; $(e, f)$ OW6-C2. The same areas of the cell cultures are shown in $(a, c, e)$ fluorescent light; $(b, d, f)$ under phase contrast conditions. Further details were as described in the legend of fig. 1. 
Table 5. Gap junction frequency and size in Chinese hamster mec ${ }^{+}$and $\mathrm{mec}^{-}$ cells

\begin{tabular}{llllll}
\hline $\begin{array}{l}\text { Name of } \\
\text { cells }\end{array}$ & $\begin{array}{l}\text { Total membrane } \\
\text { area scanned } \\
\left(\mu \mathrm{m}^{2}\right)\end{array}$ & $\begin{array}{l}\text { Total area of } \\
\text { gap junction } \\
\text { plaques } \\
\left(\mu \mathrm{m}^{2}\right)\end{array}$ & $\begin{array}{l}\text { Total no. of } \\
\text { gap junction } \\
\text { plaques found }\end{array}$ & $\begin{array}{l}\text { Average area } \\
\text { of gap junc- } \\
\text { tion plaques } \\
\left(\mu \mathrm{m}^{2} \pm \mathrm{SD}\right)\end{array}$ & $\begin{array}{l}\text { No. of } \\
\text { junctional } \\
\text { particles } \\
( \pm \mathrm{SD})\end{array}$ \\
\hline Wg3-h-o & 1580.3 & 0.206 & 14 & $0.0147 \pm 0.019$ & $109 \pm 103$ \\
CI-4 & 1580.8 & 0 & 0 & 0 & 0 \\
\hline
\end{tabular}

Details of the analytical conditions are described under Materials and Methods. For each cell line 75 unit squares $\left(2.050 \mu \mathrm{m}^{2}\right.$ each) on electronmicroscopic grids were scanned. The gap junction plaques in $\mathrm{Wg} 3$-h-o cells varied in size between 0.001 and $0.068 \mu \mathrm{m}^{2}$. The number of junctional particles per gap junction plaque varied between 17 and 346 .

caused in most cases analyzed a slightly reduced autoradiographic background of the recipient cells not in contact with donor cells. This is indicated by the threshold values listed in table 4 . After fluorescent dye injection the stimulatory effect on cell-cell coupling of an extracellular matrix was relatively small or could not be found with CI-4/DON cell pairs or pairs of mouse L cells (A9/LMTK ${ }^{-}$), respectively (cf table 2). A 1.5- to 2-fold stimulation of an extracellular matrix on metabolic corporation was found in the autoradiographic analysis when mouse $\mathrm{L}$

Table 6. Survival cloning after cocultivation of parental cells or somatic cell hybrids with the mouse embryonal carcinoma cell line OC15S1

\begin{tabular}{lcl}
\hline Name of cell line & $\begin{array}{l}\text { \% Survival } \\
\text { cloning }\end{array}$ & $\begin{array}{l}\text { Assigned } \\
\text { phenotype }\end{array}$ \\
\hline $\begin{array}{l}\text { Parental cells } \\
\text { Wg3-h-o-T }\end{array}$ & 0.5 & $\begin{array}{l}\mathrm{mec}^{+} \\
\mathrm{mec}^{-}\end{array}$ \\
CI-4 & 81 & \\
Hybrids & & \\
OW4 & 10 & $\mathrm{mec}^{+}$ \\
OW4-C2 & 78 & $\mathrm{mec}^{-}$ \\
OW6 & 7 & $\mathrm{mec}^{+}$ \\
OW6-C2 & 77 & $\mathrm{mec}^{-}$ \\
OW9 & 18 & $\mathrm{mec}^{(+)}$ \\
OW9-CI & 79 & $\mathrm{mec}^{-}$ \\
10 BW6 & 6 & $\mathrm{mec}^{+}$ \\
20 BW4 & 0.7 & $\mathrm{mec}^{+}$ \\
50 BW3 & 81 & $\mathrm{mec}^{-}$ \\
50 BW6 & 9 & $\mathrm{mec}^{+}$ \\
50 BW12 & 8 & $\mathrm{mec}^{+}$ \\
\hline
\end{tabular}

For details of the survival cloning assay and the isolation of somatic cell hybrids see Materials and Methods. $\mathrm{mec}^{(+)}$means that the $\mathrm{mec}^{+}$phenotype is only weakly expressed.
Table 7. Cell-cell coupling in somatic cell hybrids detected after microinjection of $\mathrm{Lu}$ cifer yellow

\begin{tabular}{llll}
\hline $\begin{array}{l}\text { Name of } \\
\text { cells in } \\
\text { contact }\end{array}$ & $\begin{array}{l}\text { Total no. } \\
\text { of injected } \\
\text { cells }\end{array}$ & $\begin{array}{l}\text { No. of } \\
\text { positive } \\
\text { contacts }^{a}\end{array}$ & $\begin{array}{l}\% \text { Positive } \\
\text { contacts }\end{array}$ \\
\hline OW6 & 46 & 32 & 70 \\
OW6-C2 & 30 & 0 & 0 \\
OW9 & 53 & 4 & 8 \\
OW9-CI & 52 & 4 & 8 \\
10 BW6 & 26 & 6 & 23 \\
20 BW4 & 28 & 8 & 29 \\
50 BW3 & 19 & 3 & 16 \\
BALB/c & & & \\
embryonic & & & 100 \\
fibroblasts & 25 & 25 & \\
\hline
\end{tabular}

For details of culture conditions, microinjections, and fluorescence microscopy see Materials and Methods.

a Number of cases where spreading of Lucifer yellow to at least one contiguous cell has been observed. 
cells were cocultured with each other (A9/LMTK ${ }^{-}$cells) or when human fibrosarcoma cells HT1080-T4 (HPRT $^{-}$) were cocultured with HT1080 cells (HPRT $^{+}$) (table 4). Azarnia et al. [5] have recently reported that mouse L cells can couple with each other when growing at a similar low cell density as used in our autoradiographic analysis of cell-cell coupling.

\section{Morphometric analysis of gap junction plaques}

We were interested to search for gap junction plaques in the Chinese hamster cells selected for the $\mathrm{mec}^{-}$phenotype. Thus we analyzed the appearance of gap junction plaques on freeze-fractured surfaces of cultured CI-4 cells and the parental Wg3-h-o cells. Table 5 lists the quantitative results. No gap junction plaques could be detected in cultured contiguous $\mathrm{CI}-4$ cells, whereas 14 gap junction plaques were found in Wg3-h-o cells. Fig. 3 illustrates the morphology of these plaques. It is not clear whether the loose aggregates of intramembrane particles occasionally found in CI-4 cells (fig. 4) bear any biochemical relationship with the similar sized particles of gap junctions. Since pits complementary to the intramembrane particles were never found on $\mathrm{E}$ faces it seems unlikely that these aggregates represent functional gap junctions. The absence of gap junction plaques among contiguous CI-4 cells is in line with our finding that no functioning cell-cell coupling could be demonstrated between these cells in the survival cloning assay, the dye injection assay, or by electrical measurements. Cocultures of CI-4/DON cells could not be studied by electron microscopy since both cells could not be distinguished under these conditions.

Restoration of cell-cell coupling in somatic cell hybrids

We carried out a somatic cell genetic analysis of hybrids isolated after fusion of CI-4 cells with either mouse embryonal carcinoma OC15S1 cells or with embry-

Table 8. Isozyme analysis in extracts of somatic cell hybrids

\begin{tabular}{|c|c|c|c|c|c|c|c|c|c|}
\hline \multirow{2}{*}{$\begin{array}{l}\text { Name of } \\
\text { cell } \\
\text { hybrid }\end{array}$} & \multirow{2}{*}{$\begin{array}{l}\text { Phenotype } \\
\text { metabolic } \\
\text { cooperation }\end{array}$} & \multicolumn{8}{|c|}{ Expression of mouse isozymes assigned to (mouse chromosomes) } \\
\hline & & $\begin{array}{l}\text { PEP-3 } \\
\text { (1) }\end{array}$ & $\begin{array}{l}\text { AK-1 } \\
\text { (2) }\end{array}$ & $\begin{array}{l}\text { PGM-2 } \\
\text { (4) }\end{array}$ & $\begin{array}{l}\text { PGM-1 } \\
\text { (5) }\end{array}$ & $\begin{array}{l}\text { TPI } \\
\text { (6) }\end{array}$ & $\begin{array}{l}\text { GPI } \\
(7)\end{array}$ & $\begin{array}{l}\text { APRT } \\
\text { (8) }\end{array}$ & $\begin{array}{l}\text { MPI } \\
(9)\end{array}$ \\
\hline OW4 ${ }^{a}$ & $\mathrm{mec}^{+}$ & + & + & + & - & + & - & - & + \\
\hline OW4-C2 ${ }^{\mathrm{a}}$ & $\mathrm{mec}^{-}$ & - & + & + & - & + & - & - & - \\
\hline OW6 & $\mathrm{mec}^{+}$ & + & + & + & $(+)$ & + & $(+)$ & + & + \\
\hline OW6-C2 & $\mathrm{mec}^{-}$ & - & - & - & - & - & - & + & - \\
\hline OW9 & $\mathrm{mec}^{(+)}$ & - & + & + & - & - & + & + & - \\
\hline OW9-CI & $\mathrm{mec}^{-}$ & - & - & $(t)$ & - & - & + & + & - \\
\hline $10 \mathrm{BW6}$ & $\mathrm{mec}^{+}$ & + & + & + & - & $(+)$ & + & + & - \\
\hline $20 \mathrm{BW} 4$ & $\mathrm{mec}^{+}$ & - & + & $(+)$ & + & + & + & + & $(+)$ \\
\hline $50 \mathrm{BW} 3$ & $\mathrm{mec}^{-}$ & - & - & $(+)$ & $(+)$ & + & $(+)$ & - & - \\
\hline 50 BW6 & $\mathrm{mec}^{+}$ & + & + & + & + & $(+)$ & + & + & $(+)$ \\
\hline $50 \mathrm{BW} 12$ & $\mathrm{mec}^{+}$ & + & + & + & + & + & + & + & $(+)$ \\
\hline
\end{tabular}

The names of isozymes, EC numbers, and the assay conditions are outlined under Materials and Methods.

${ }^{a}$ For hybrids OW4 and OW4-C2 karyotype analyses have been carried out which confirmed the results of the 
onic BALB/c mouse fibroblasts. The hybrid nature of the clones was proven by isozyme analysis and in two cases by karyotype analysis (see next paragraph). In order to analyze these hybrids in the survival cloning assay we counter-selected all hybrids in the presence of thioguanine and obtained $\mathrm{HPRT}^{-}$derivatives. These counter-selected derivatives were cocultured with OC15S1 cells, as detailed under Materials and Methods. Table 6 lists the data of survival cloning for parental cells and derived somatic cell hybrids. The survival cloning assays were carried out with OC15S1 cells rather than DON cells as donor cells (HPRT ${ }^{+}$). We expected that Chinese hamster hybrids with restored cell-cell coupling due to the expression of mouse chromosomes might better communicate via gap junctions with mouse cells rather than Chinese hamster cells. Embryonic BALB/c mouse fibroblasts were less suitable than OC15S1 cells for this purpose, since the latter detached much faster in thioguanine-containing medium from the plastic surface of the tissue culture flasks. In pilot experiments we observed that Chinese hamster $\times$ mouse hybrids with restored cell-cell coupling exhibited lower percentages of survival cloning with OC15S1 cells rather than BALB/c fibroblasts (data not shown). Thus we carried out all survival cloning assays of hybrids with OC15S1 cells. We grew three hybrids (OW4, OW6, and OW9) under conditions of cocultivation together with OC15S1 cells in the presence of thioguanine and picked two surviving clones of each parental hybrid. In a second cycle of cocultivation experiments with OC15S1 cells from these two hybrids that derivative was chosen which showed the highest percentage of survival cloning similar to the $\mathrm{mec}^{-}$cell line $\mathrm{CI}-4$. We assigned $\mathrm{mec}^{-}$or $\mathrm{mec}^{+}$phenotypes to the somatic cell hybrids according to their percentage of survival cloning. This simplified the comparison with the isozyme data of table 8 .

We also studied cell-cell coupling in some of these hybrid cells by microinjection of fluorescent Lucifer yellow (table 7, fig. 4). In most cases these results

\begin{tabular}{lllllllll}
\hline $\begin{array}{l}\text { PEP-2 } \\
(10)\end{array}$ & $\begin{array}{l}\text { GALK } \\
(11)\end{array}$ & $\begin{array}{l}\text { ACP-1 } \\
(12)\end{array}$ & $\begin{array}{l}\text { ES-D } \\
(14)\end{array}$ & $\begin{array}{l}\text { SOD-1 } \\
(16)\end{array}$ & $\begin{array}{l}\text { GLO-1 } \\
(17)\end{array}$ & $\begin{array}{l}\text { PEP-1 } \\
(18)\end{array}$ & $\begin{array}{l}\text { GOT-1 } \\
(19)\end{array}$ & $\begin{array}{l}\text { HPRT } \\
(x)\end{array}$ \\
\hline+ & - & + & + & + & + & + & + & - \\
- & - & - & + & - & + & + & - & - \\
+ & - & - & + & + & + & + & + & - \\
- & - & - & + & - & - & - & - & - \\
+ & + & + & - & + & + & - & + & - \\
- & - & - & - & - & - & - & + & - \\
+ & + & + & $(+)$ & + & - & - & + & - \\
- & - & + & + & + & - & - & + & - \\
- & - & - & - & - & - & - & + & - \\
- & - & $(+)$ & - & + & - & ++ & + & - \\
$(+)$ & - & + & + & + & - & - & + & - \\
\hline
\end{tabular}

isozyme studies. In addition the presence or absence of chromosomes 3, 13, and 15 has been determined by these karyotype analysis (see text).

(+) Corresponding isozyme activity of phenotypes is weakly expressed (near the limit of detection). 
confirm the conclusions drawn from the survival cloning data (table 6), i.e., those hybrid clones which showed a low percentage of survival cloning gave relatively high percentages of positive contacts in the dye injection assay. The results of both assays are not expected to be directly proportional, however. The spreading of Lucifer yellow was measured in homogeneous cultures of a given hybrid, whereas survival cloning data were obtained in cocultures of hybrid cells and OC15S1 cells. Since it is likely that frequently not all cells of a hybrid cell clone contain a given mouse chromosome necessary for cell-cell coupling, it is conceivable that in certain cases a lower number of positive contacts was found for dye transfer than in survival cloning. Furthermore, the cloning survival assay is likely to have a greater sensitivity than the dye injection method. This may explain why hybrid clone OW9 showed a relatively low percentage of survival cloning, but very few positive contacts after Lucifer yellow injections. In a previous paper [25] we had determined that our assay conditions allowed to detect an isozyme activity (or a mouse chromosome) when it was present in as few as $5 \%$ of the hybrid cells. We noticed that all hybrids exhibited the lowest percentage of survival cloning shortly after isolation and counterselection with thioguanine (data not shown). In subsequent assays, after about one month of continuous culturing, an increase of 3-5\% was noticed with most original hybrids. With the hybrid clone OW9 we found an increase of survival cloning from originally $5 \%$ to $8 \%$. Most likely, this was due to loss of mouse chromosomes from these interspecific hybrids.

\section{Isozyme and karyotype analyses of Chinese hamster $\times$ mouse hybrids}

Table 8 summarizes the results of isozyme analysis in extracts of hybrid cells. We assayed seventeen different mouse isozyme activities whose genes had been assigned to seventeen different mouse chromosomes, assuming a normal mouse karyotype like in embryonic BALB/c fibroblasts. The mouse teratocarcinoma cells OC15S1 were previously shown to have a modal number of forty mouse chromosomes, all of which were morphologically normal according to their Giemsa banding pattern, except one abnormal marker chromosome [12]. This was confirmed by our own karyotype analysis (twenty-nine metaphase spreads counted). Thus we tentatively assumed that the $\mathrm{mec}^{-}$defect of CI-4 cells can be complemented in OW and BW hybrids by the same normal mouse chromosomes. Our data of isozyme analysis suggested that the expression of mouse superoxide dismutase (assigned to mouse chromosome 16) appeared to cosegregate with the $\mathrm{mec}^{+}$phenotype in the Chinese hamster $\times$mouse hybrids. Alternatively any of mouse chromosomes 3,13 , or 15 which were not assayed by mouse isozymes could complement the $\mathrm{mec}^{-}$defect in CI-4 cells. Therefore, we analyzed the karyotypes of hybrid OW4 $\left(\mathrm{mec}^{+}\right)$and its counterselected derivative OW4-C2 $\left(\mathrm{mec}^{-}\right.$) (twenty metaphase spreads analyzed cach). Mouse chromosomes 3 and 5 were detected in both hybrids, whereas neither the $\mathrm{mec}^{+}$hybrid nor the $\mathrm{mec}^{-}$ hybrid contained mouse chromosome 13. Thus, none of these chromosomes segregated with the $\mathrm{mec}^{+}$phenotype in this hybrid. Thus we tentatively conclude from the comparison of tables 6 and 7 that a gene located on mouse chromosome 16 could be involved in complementation of the $\mathrm{mec}^{-}$defect in CI- 4 cells. It 
should be emphasized that this chromosome assignment is a preliminary working hypothesis and has to be confirmed by karyotype analysis of more hybrid cell clones.

\section{DISCUSSION}

We conclude from the results of our different experimental approaches to measure cell-cell coupling among CI- 4 cells that these cells have almost completely lost the capability to form functioning gap junctions with cach other. After injection of fluorescent Lucifer yellow we detected up to $9 \%$ positive contacts among confluent CI-4 cells grown in the presence of db-cAMP. Thus, even though the CI-4 cells were selected in the presence of cAMP they still responded to the drug with a slight increase in cell-cell coupling. The results of survival cloning do not show an increase in metabolic cooperation under these conditions. The electrical measurements suggest that the CI-4 cells can exhibit junctional permeability with DON wild-type cells, although only about one seventh as efficiently as DON cells among each other. According to our autoradiographic studies of metabolic cooperation the CI-4 cells can form positive contacts with DON cells about one sixth as efficiently as their parental Wg3-h-o cells. Our experiments do not allow us an estimation of the number of functional gap junction channels between the cells. Thus it is possible that only relatively few functioning channels between CI-4 and DON cells are sufficient to give a positive result, whereas in DON/DON cell pairs gap junctions may be much more trequent.

The results of characterizing the CI-4 cells with the survival cloning assay, the fluorescent dye injection, and the electrical, as well as autoradiographic measurements are in good agreement with each other. When cocultured with DON cells on an extracellular matrix the CI-4 cells showed autoradiographically 4-fold more positive contacts of metabolic cooperation than in the absence of the extracellular matrix. A stimulatory effect of the extracellular matrix on the percentage of positive contacts in metabolic cooperation has been also found with mouse $\mathrm{L}$ cells and human fibrosarcoma cells. These cells had been characterized before as defective in metabolic cooperation [cf 26]. Using the assay of Lucifer yellow injection we found only a relatively low increase of positive contacts for the cell pair CI-4/DON when cocultured on an extracellular matrix (cf table 2). It is tempting to speculate that proteins of the extracellular matrix may stabilize gapjunctional cell-cell contacts with neoplastically transformed cells of $\mathrm{mec}^{-}$phenotype. This may lead to the observed increase of metabolic cooperation. Further experiments will have to clarify the extent and the molecular basis of this effect.

We conclude from our experiments that the number of functional gap junction channels appears to be reduced in CI-4 cells compared to their parental cells. It is possible that $\mathrm{CI}-4$ cells contain less gap junction protein than their parental cells. Recently antisera against purified denatured gap junction protein from mouse liver have been characterized in this laboratory [27]. These antisera do react with the corresponding $26 \mathrm{~K}$ protein from the liver of Chinese hamsters $(\mathrm{O}$. Traub, unpublished experiments). If these antisera specifically recognize the gap junc- 
tion protein from Chinese hamster fibroblasts, too, they could be used to compare the total amounts of gap junction protein in $\mathrm{Wg} 3-\mathrm{h}-\mathrm{o}-\mathrm{T}$ cells and in CI-4 cells.

The selection conditions which we and others [8] have used for isolation of $\mathrm{mec}^{-}$cells can be overcome by many different cellular defects which prevent the lethal effects of thioguanine, even when they are only indirectly related to gap junction function. For example, defects affecting the pool of nucleotides, cellular adhesion, mobility of the cells, or density-dependent regulation of growth may lead to the $\mathrm{mec}^{-}$phenotype. The variety of these possible lesions may explain-in addition to technical difficulties of the selection system-that $\mathrm{mec}^{-}$ cells appear in the first selection cycle at least 10 -fold more frequently than expected for mutants harboring deletions in a single gene. It is not clear whether multiple mutations were required for the $\mathrm{CI}-4$ cells to become $\mathrm{mec}^{-}$. Our complementation studies using somatic cell hybrids tentatively suggest that mouse chromosome 16 can complement the mec $^{-}$defect in CI-4 cells. The involvement of other mouse chromosomes cannot be excluded. Previously it was reported that human chromosome 11 can complement the spontaneous $\mathrm{mec}^{-}$ defect of mouse $\mathrm{L}$ cells in somatic cell hybrids with human fibroblasts [28]. Recently McDonald [29] has shown, using the autoradiographic assay of metabolic cooperation, that functional reconstitution of the $\mathrm{mec}^{+}$phenotype can be demonstrated in somatic cell hybrids of the selected $\mathrm{mec}^{-}$mouse embryonal carcinoma cells and the spontaneous $\mathrm{mec}^{-}$mouse $\mathrm{L}$ cells. Thus the $\mathrm{mec}^{-}$ defects of both cell lines are probably independent of each other. Similar experiments with the CI-4 cells may lead to further genetic dissection of the $\mathrm{mec}^{-}$ phenotype.

Since the CI-4 cells appear to have a very low background of residual cell-cell coupling activity when assayed with fluorescent-dye injection as well as with electrical measurements they may be useful for reconstitution of functional cell-cell coupling using isolated gap junction protein. No such studies have been reported yet, although much of the present controversy regarding the protein components of functional gap junctions [30] could be resolved if functional reconstitution could be demonstrated.

We acknowledge the technical help of Ms Ingeborg Rademacher, Waltraud Kuß, and Dorothea Schünke. This work has been supported by grants from the Ministerium für Wissenschaft und Forschung, Düsseldorf, and in part from the Deutsche Forschungsgemeinschaft (Wi 270/11) to K.W.

\section{REFERENCES}

1. Loewenstein, W R, Physiol rev 61 (1981) 829.

2. Hooper, M L \& Subak-Sharpe, J H, Int rev cytol 69 (1980) 45.

3. Gilula, N B, Reeves, O R \& Steinbach, A, Nature 235 (1972) 262.

4. Loewenstein, W R, Biochim biophys acta 560 (1979) 1.

5. Azarnia, R, Dahl, G \& Loewenstein, W R, J membrane biol 63 (1981) 133.

6. Wright, E D, Goldfarb, P S G \& Subak-Sharpe, J H, Exp cell res 103 (1976) 63.

7. Wright, E D, Slack, C, Goldfarb, P S G \& Subak-Sharpe, J H, Exp cell res 103 (1976) 79.

8. Slack, C, Morgan, R H M \& Hooper, M L, Exp cell res 117 (1978) 195.

9. Hooper, M L, Biochim biophys acta 651 (1982) 85 .

10. Hooper, M L \& Parry, J E, Exp cell res 128 (1980) 461. 
11. Hooper, M L \& Morgan, R H M, Exp cell res 123 (1979) 392.

12. Davies, P J \& Willecke, K, Mol gen genet 154 (1977) 191.

13. McBurney, M, J cell physiol 89 (1976) 441.

14. Willecke, K, Lange, R, Krüger, A \& Reber, T, Proc natl acad sci US 73 (1976) 1274.

15. Szybalska, E H \& Szybalski, W, Proc natl acad sci US 48 (1962) 2026.

16. Littlefield, J W, Science 145 (1964) 709.

17. Russel, W C, Newman, C \& Williamson, D H, Nature 253 (1975) 401.

18. Stewart, W W, Cell 14 (1978) 741.

19. Graessmann, A, Graessmann, M \& Mueller, C, Methods enzymol 65 (1980) 816.

20. Hülser, D, Methods cell biol VIII (1974) 289.

21. Gaunt, S J \& Subak-Sharpe, J H, Exp cell res 120 (1979) 307.

22. Chen, L B, Cell 14 (1978) 377.

23. Davidson, R \& Ephrussi, B, Exp cell res 61 (1970) 222.

24. Schäfer, $R$, Hoffmann, H \& Willecke, K, Cancer res (1983). In press.

25. Schäfer, R, Doehmer, J, Drüge, P M, Rademacher, I \& Willecke, K, Cancer res 41 (1981) 1214.

26. Corsaro, C M \& Migeon, B R, Proc natl acad sci US 74 (1977) 4476.

27. Traub, O, Janßen-Timmen, U, Drüge, P M, Dermietzel, R \& Willecke, K, J supramol struct cell biochem 19 (1982) 27.

28. Loewenstein, W R, Differentiation and development (ed F Ahmad, J Schultz, T R Russel \& R Werner) pp. 399-409. Academic Press, New York (1978).

29. McDonald, C, Exp cell res 138 (1982) 303.

30. Finbow, M, Yancey, S B, Johnson, R \& Revel, J-P, Proc natl acad sci US 77 (1978) 970.

Received July 15, 1982

Revised version received September 21, 1982 